NB This is the corrected manuscript of an article published in Grey Room 83 (Spring 2021), (C) MIT Press, https://direct.mit.edu/grey, https://direct.mit.edu/grey/article/doi/10.1162/grey_a_00320/102378/Atmospheric$\underline{\text { Regulation-in-the-Panorama }}$

\title{
Atmospheric Regulation in the Panorama
}

\section{Nicholas Robbins}

In 1821 and 1822, the ball and cross that crowned the dome of St. Paul's Cathedral were slated for replacement, and a scaffolding was erected around its summit. In this moment, the entrepreneurial surveyor Thomas Hornor spotted an opportunity. Installing himself upon the scaffolding during the summer of 1821 , he executed a series of sketches with the aim of publishing a series of panoramic engravings of London. A more significant vantage point from which to view the city could hardly be imagined: St Paul's was the very fulcrum around which London's landscape unfolded. ${ }^{1}$ Yet, the cover of Hornor's Prospectus for the series of engravings shows not the view from above but the silhouetted form of St. Paul's dome and cross, above which floats an orb of light materialized by the reserve of the paper. Radiating from this orb, streaks of light penetrate and dispel the gloom of London's atmosphere, inscribed as if by wiping accumulated soot from the page.

The view "from above," in this instance, is predicated on contending with air itself - a medium of vision that, in early nineteenth-century London, was an agent of obscurity rather than of transparence. Through his careful process of observing and recording the city's landscape "with mathematical accuracy," Hornor aimed to produce a counterfactual image of the city from which its smoky air had been excised. The opacity and insalubrity of London's air had long been an object of concern. The particulate matter thrown into the atmosphere by the burning of "sea- 
coale" had driven the writer and experimentalist John Evelyn to publish his Fumifugium (1661), in which he proposed various means for "Meliorating and refining the Aer of London," including moving fuel-intensive manufactures out of the city and planting gardens to dissipate the smell. ${ }^{2}$ The problems Evelyn articulated had only intensified in the intervening century and a half. The early decades of the nineteenth century saw an explosive growth in London's population, from one million in 1800 to almost two million by 1830 , growth accompanied by a steep rise in domestic and industrial fires. ${ }^{3}$ From 1819 to 1821 , the House of Commons took up its first (ineffective) efforts at crafting legislation that might regulate and reduce the amount of smoke choking Britain's urban and rural landscapes. ${ }^{4}$ Manufacturers and inventors contributed designs for smoke-consuming chimneys, such as one that aimed to reduce emissions by metrically delineated "degrees of smoke."

Hornor's iterative project of recording London's landscape from above should be seen in this context. Although he abandoned his planned set of prints, Hornor used his sketches as the basis for a vast panoramic painting installed in the purpose-built Colosseum on Regent's Park. This panorama took its place within the cascading "panoramania" set off by Robert Barker's opening of the first purpose-built panorama in London in $1793 .{ }^{6}$ The panoramic structure, which fuses the painted image with the space surrounding it, is designed to produce and contain a controlled, circumambient aerial medium of vision. ${ }^{7}$ In Hornor's panorama of London, this material manipulation of air as a perceptual medium in the panoramic apparatus was joined with his visual production of a counterfactual, smokeless city.

The panorama is familiarly posited as one of the techniques of nineteenth-century disciplinary culture and imperial visuality. ${ }^{8}$ This article suggests that, in Hornor's case, the regulation of atmosphere was central to the function of such discipline- one exerted not 
necessarily upon the bodies of visitors but upon the vaporous matter of the city itself. ${ }^{9}$ Hornor's panorama thus joins a longer genealogy of architectural modes of regulation developed to impose order on what Michael Osman calls the "errors and deviations endemic to a society invested in growth."10 The modes of financial speculation that had shaped London's cacophonous built environment - the intense growth of its population and aerial obscurity — are central to the story. But Hornor's work of atmospheric regulation had begun in his prior career as a private surveyor and producer of aerial views of rural estates. The visual techniques upon which his panoramic apparatus builds stem not from the visuality of the military or the imperial state but from real estate speculation and the links it forged between rural sites of agriculture and industry and the rapidly expanding city. The coal dug from the ground around these estates would, in time, be transformed into the matter crowding London's air. Hornor transferred this privatized, speculative vision of landscape to the top of St. Paul's, a vision that took place within a broader "commodification" of the visual experience of London in a period of rapid growth, as Dana Arnold has shown. ${ }^{11}$ The Colosseum's panorama offered a vision of transparency that served the interests of property owners and the version of order that they aimed to impose upon the landscape — one most spectacularly evident in the development of the Regent's Park of which the Colosseum was one part. Yet, the regulated atmosphere of Hornor's panorama could control neither the interpretations of the city's landscape that its transparency elicited nor the behavior of the visitors who ascended its vertical viewing platform.

\section{Placed as It Were in the Air}

As with the panoramic image in general, Hornor's project had a foundation in the work of surveying. In 1808, he had been commissioned to produce a survey of the parish of 
Clerkenwell. ${ }^{12}$ He quickly shifted to work on lucrative estate mapping, especially for properties owned by wealthy London businessmen. The large expansion of opportunities for private surveyors came on the heels of the Parliamentary enclosures. ${ }^{13}$ Particularly in the period after 1750 , these acts intensified the ongoing conversion of rural common lands into commodified tracts, terrains whose productivity was managed by the related conversion of agricultural work into wage labor. As a long tradition of art-historical scholarship has established, enclosure shaped the development of landscape painting in Britain, which simultaneously represented the interests of the property owner while suppressing the increasingly regulated, even industrialized nature of the agricultural landscape. ${ }^{14}$ If landscape painting thus aimed to perpetuate the myth of the "organic" community of rural landscapes from a land-bound perspective, the lofty eye of the survey (and its more privatized, instrumental functions) was shaped more baldly by the quantifying exigencies of property and capital. ${ }^{15}$

Hornor's self-proclaimed innovation, announced in his 1813 Improved Method of Delineating Estates, was to leaven the survey's graphic language of triangulated space and diagrammatic legibility by integrating it with what he called the "pictural" characteristics of landscape. The term he coined for his surveys, "panoramic chorometry," combines the aerial nature of panoramic vision, the bounded and proprietary territorial imagination of chorography, and the mensurational imperative of surveying. ${ }^{16}$ As such, his surveys aimed to compress terrestrial organicism and aerial quantification into one view. ${ }^{17}$ The "beholder" of the lavish surveys, such as that of the estate of Rheola in South Wales, is "placed as it were in the air," able to see what would otherwise be hidden by the landscape's "irregularity." 18 Yet this aerial position did not simply represent possession: the intervening atmosphere between this aerial "beholder" and the landscape could be manipulated to increase the attractiveness of the view. 
The shadows cast by clouds, for example, could be represented such that the "interadjacent tracts" that separated parcels of land owned by the survey's patron could be "either thrown into obscurity or totally concealed" by means of selective chiaroscuro. ${ }^{19}$

Thus the aerial position of Hornor's surveys was both inclusive and exclusive. Such exclusion of parts of the landscape that did not contribute to the representation of the property's value — further dividing continuous terrain into enclosed parcels—-was effected by a kind of vertically oriented atmospheric perspective. Leonardo da Vinci's Treatise on Painting, newly translated into English in 1802, provided the foundational account of atmospheric perspective, describing how the "great quantity of air" intervening between objects and the spectator's eye "tinges objects" with color, transforming their appearance and relative prominence. ${ }^{20}$ The blued, obscuring effect of air, translated into paint, served to ratify the spatial distances contained within a view—arranging the elements of a landscape into an ordered recession controlled by what artist T.H. Fielding termed in 1829 the "superior regulations of aerial perspective." ${ }^{21}$ In Hornor's vertically oriented variant, atmosphere could thus be reorganized to obscure elements of the landscape viewed from above in order to increase the perceived value of the property. ${ }^{22}$ The appealing views that resulted, which emphasized the extent of the land while minimizing its defects or noncontiguity, would, Hornor claimed, be "obviously serviceable in the transfer of landed property. ${ }^{, 23}$ Here the survey is both a means of possession and of transaction, a medium of accumulating wealth through its imagined conveyance — given that his surveys could be used to "attract purchasers by placing the whole property in the most favourable point of view."24

The terrains Hornor surveyed are of equal interest to his techniques. The Rheola estate represented in Hornor's survey, for example, had been inherited by the London-based solicitor and speculator John Edwards Vaughan. ${ }^{25}$ Edwards Vaughan then hired architect John Nash to 
redesign the Rheola residence. This choice was not arbitrary. Nash was Edwards Vaughan's cousin, and they would continue to have a close association-Edwards Vaughan, for one, was an investor in and solicitor for Nash's Regent's Canal Company. ${ }^{26}$ His relationship with Nash, according to one biographer, "confirmed the widespread prejudice against [Vaughan Edwards] as a speculator and adventurer." ${ }^{27}$ Edwards Vaughan's business interests linked the rural landscape of Rheola with the spaces of rapidly expanding London. One key aspect of the rural landscape's commodification in this period was the expansion of mineral extraction and the increasing industrialization of South Wales, as attested in Hornor's dramatic watercolor of one of the ironworks in Merthyr Tydfil powered by local coal. ${ }^{28}$ The Rheola estates and surrounding areas in the Neath and Rhondda Valleys contained enormous coal deposits, newly accessible by canals and turnpikes, and eventually by railroad. ${ }^{29}$ Coal mining thus turned South Wales into a repository for an energy source that had transformed London's air, just as the blaring light from ironworks cuts dramatic lines through the smoky night air of Hornor's watercolor.$^{30}$ Hornor's later ventures in London would develop out of this network of patrons and the nexus of enclosure, speculation, and extraction.

\section{A Misty Medium}

This speculative vision — and its atmospheric calibrations — shaped Hornor's work on his planned set of views of London. Turning over the cover of the Prospectus, with its streaky, illuminated haze, we are met with a frontispiece that brings Hornor's aerial position into sharper view. At the top of the engraving is the summit of St. Paul's dome and its scaffolding, floating like a balloon above a more conventional prospect of London seen from across the Thames. ${ }^{31}$ In the lower segment of the image, one that conditions another shift of perspective, we see Hornor's 
observatory on St. Paul's, viewed from above. The inclusion of this small, rickety perch ratifies and authenticates the position of Hornor's observation, even as it simultaneously dislocates it within the image's fragmented scalar shifts. ${ }^{32}$

The multiplicity of viewpoints indicated in the frontispiece diagrams the multiplied and reversible gaze that structured Hornor's process of observing London over the course of the summer of 1821. The bulk of his Prospectus is concerned with descriptions of the four proposed views, in which he imagines various visual trajectories through the city, narrating and giving order to London's rapid expansion in the prior decades from this elevated viewpoint. Yet Hornor's imagined aerial view was structured by a reciprocal set of gazes. The "object of the Artist," he writes, is not necessarily to depict the view from St. Paul's but instead to show every place in London and its environs "from which the ball and cross of St. Paul's are visible." ${ }^{33}$ This description thus sutures two axes of vision: Hornor's own view, perched atop the cathedral's dome, but also the returning view toward the summit, an earth-bound perspective linked to Hornor's practices as a surveyor. ${ }^{34}$ Hornor identified this returning gaze with London's property owners. He prepared a notice to "Possessors of Property" in London "from which the Cross of St. Paul's can be seen" to send him a description of their property—whether warehouse or villa - so that he could best describe the "interest or beauty, whether of artistic, commercial, or rural character, identified by the owner" in his finished engravings. ${ }^{35}$ Hornor's prints were thus intended to deliver a view of the city as an orderly whole that nevertheless integrated what John Barrell describes as the "private appetites and interests of particular men"- a self-interested viewer who was considered, in period aesthetic thought, to be incapable of apprehending a wider, unifying "prospect." 36 
The array of images in his Prospectus showing Hornor's observational apparatus — such as one that labels each part of the structure as if it were a scientific instrument-amplified the extended, highly regulated nature of the labor Hornor expended on his proposed prints. ${ }^{37}$ The summer in his observatory was defined by Hornor's attempts to work against the contingency and obscurity of London's atmosphere. As he describes in the Prospectus, he made daily visits to his St. Paul's observatory in the very early morning so that he might begin his work of sketching "before the smoke began to ascend." Yet he is quick to note, "at no one time is it possible, however clear the atmosphere, to command, from the situation alluded to a distinct view of the entire circle of the metropolis." This impossibility of a simultaneous, circumambient view from the dome was the impetus for the project. In his engravings, he imagined that, finally, the entirety of London might be seen together, "at the most favourable moment." This regulatory vision of urban order required the management of London's atmosphere. Only then would they then form "collectively a whole, freed from all those disadvantages of smoke or shade by which the real scene is ever greatly obscured." 38

Even having evaded the obscuring agency of smoke, Hornor had also to contend with the fundamental variability of the weather itself. "In weather partially cloudy portions of the scene would be in bright sunshine and others in total obscurity, producing an incessant alternation of light and shade." His solution to this problem of shifting illumination was to proceed by fragments or "component parts.” By sketching small portions of the city while viewing them through a graphic telescope, which framed and magnified the view, Hornor could take advantage of any areas of "clear light" while they lasted and make an "immediate transition ... from one sketch to the another" as the weather shifted. ${ }^{39}$ The entire structure of the observatory reportedly rotated so Hornor might turn his gaze upon whichever section of the city was currently 
illuminated. ${ }^{40}$ Such fragments would then later be collated into a view of the city, one freed from atmospheric irregularity.

Hornor was far from alone in his attempts to manage the London's obscured atmosphere within pictorial and panoramic space. What distinguished his project was that, rather than attempting to translate the unpredictable materiality of London's air into the medium of paint or watercolor, his aim was to excise it entirely. Hornor's imagined view is distinct, for example, from Thomas Girtin's 1800-1801 Eidometropolis, a panoramic painting of the city that Girtin painted from the roof of a glass factory. ${ }^{41}$ In one of the surviving working drawings for Girtin's panorama, dramatic effects of dark gray clouds obscure the view of church steeples against the view's low horizon — placing the panorama's observer within what one account called a "misty medium," whose source is specified in the dark chimney smoke of the foreground. ${ }^{42}$ Girtin's panorama, in Greg Smith's view, celebrated the kinds of dislocated, fragmented experience of urban modernity that London's cloudiness signified. ${ }^{43}$ Meanwhile, J.M.W. Turner's 1825 watercolor view of the city from Greenwich — probably made as the basis of a never-realized set of printed views of London-satirizes the city's speculative growth and its massive concentration of wealth and prosperity, as John Bonehill and Stephen Daniels argue. ${ }^{44}$ That is, Turner's view deflates precisely that aspect of the city that Hornor's prints and their solicitation of the returning gaze of the property owner sought to celebrate. Rather than presenting each “component part” of London's property for inspection, Turner dissolves the city, cast as a set of illegible marks floating in a uniformly obscured atmosphere—a "misty medium" from which St. Paul's dome barely emerges. A woman in the promontory's foreground displays two maps detailing London's massive growth, alongside other "plans" of the city and its structures. ${ }^{45}$ All of this piled-up documentation of London's density of accumulation, of which Hornor's prints 
would form yet another example, suggests a relationship between the proliferation of surveyed

landscapes — the interest in the city's growth and its accumulating wealth—and the obliterated view of the smoky metropolis beyond.

\section{Circumambient Speculation}

Hornor's print project never materialized. Instead, his view of London took on a much grander scale in the form of the panoramic painting of the city he would install in the purpose-built Colosseum, completed from 1824 to 1829. Hornor's panorama was part of the development of Regent's Park, Regent's Street, and the surrounding areas owned by the Crown into a new, genteel neighborhood for the rapidly expanding city. ${ }^{46}$ Itself a spectacular act of financial speculation, the Colosseum presented a vision of the city encased in a newly transparent "medium" of apprehension. This placing of the city under a dome seems already implicit in a drawing Hornor likely made for a second edition of his Prospectus, in which the curving surround of St. Paul's dome descends on the landscape below.

From the inception of the panoramic apparatus in Robert Barker's 1787 patent for his method of representing "La nature à coup d'œil," the control of environmental conditions within the structure received explicit attention. The "circular building or framing" built to house the image must be, Barker specifies, "lighted entirely from the top, either by a glazed dome or otherwise." The spectator is to be located in an "inclosure" within the building that "shall prevent an observer going too near the drawing or painting," which "inclosure may represent a room, or platform" that confines the observer's vision to the painted surface itself. Lastly, Barker specifies that "there should be, below the painting or drawing, proper ventilators fixed, so as to render a 
current circulation of air through the whole." ${ }^{\prime 47}$ Barker's original vision for this technology thus envisioned the panorama as a particular configuration of space, light, and air. ${ }^{48}$

Barker's apparatus built on earlier spectacles. Philippe-Jacques de Loutherbourg's 1781 Eidophusikon, for example, had presented viewers with a framed scene composed of moving parts and animated by changing light effects that reproduced the effects of weather. ${ }^{49}$ Later versions of immersive spectacle, such as Jacques-Louis Mandé Daguerre's Diorama—a version of which also opened almost adjacent to the Colosseum on Regent's Park in 1824—would similarly stage painted images set into motion by controlled daylight projected upon the front and rear of a screen. ${ }^{50}$ The manipulation of lighting to replicate meteorological effects was thus central to the period imagination of immersive visual experience. Secured within an architectural surround, Hornor's panorama integrated such control of shifting atmospheric "effect" into his static image of a smoke-cleansed London.

As suggested by Barker's repeated use of the word inclosure, the panorama might be apprehended as a form of domestication that "turns a landscape into a room." Y1 Yet this word also suggests the privatization of a "commons" of perceptual experience into a commodified enclosure — one that extends the ways landscape "improvement" supplied an ideological and structural support for the landscape painting. Barker's panorama had relocated rural techniques of enclosure into the panorama's perceptual environment. Hornor's own relationship to histories of the remaking of rural land likewise shaped his Colosseum and its role within the speculative development of Regent's Park. ${ }^{52}$

The Colosseum was designed by the young architect Decimus Burton, son of prominent property developer James Burton, who was himself deeply involved with Nash's Regent's Park enterprise. ${ }^{53}$ Working with Nash, Hornor and the younger Burton devised a building that would 
replicate the "appearance of a handsome villa." 54 In turn, the Colosseum was largely financed by Rowland Stephenson, a banker and philanthropist who had earlier commissioned Hornor to produce a pictorial survey of his estate. ${ }^{55}$ Stephenson's fraudulent financial dealings — and his ruination by speculation and by the immense expense of the Colosseum-would almost sink the project. ${ }^{56}$ The environmental "inclosure" of Hornor's panorama thus brought together the architectural and financial scene-setting of Regent's Park under the sign of techniques and professional networks that Hornor had developed in the countryside.

This speculative relationship to land, coupled with the environmental logic of control, was central to the spectacle staged at the Colosseum, which finally opened to the public in 1829. As seen in Burton's design for the Colosseum, the building encompassed a vast domed space lit by skylights, which provided the overhead illumination so crucial to the viewing space that Barker had first envisioned. After traversing a short hall, visitors entered a circular gallery. From there, they would replicate Hornor's ascent to the top of the dome, either by spiral staircase or by an "ascending-room." 57 Above the series of viewing platforms, visitors could climb to a chamber encasing the original ball and cross that had been removed from St. Paul's in the course of its renovation, and then, via another set of stairs, they would reach a platform on the Colosseum's roof. There they could view the city itself and "inhale the pure breezes of the [Park] in lieu of the smoke of the streets." 58

Hornor dramatized the process of completing the painting, as demonstrated by a set of views published by Ackermann's before the building was completed. ${ }^{59}$ Facing difficulties with realizing his view on such a large, curved surface, Hornor turned to the painter Edmund Thomas Parris. Parris had been working on the restoration of James Thornhill's fresco paintings in the interior of the dome of St. Paul's at the time Hornor was installed on the dome's roof. To 
facilitate the restoration, Parris had devised a hanging scaffolding system to allow painters access to the elevated, curved surface of the dome. While his plans for scaffolding were not used at St. Paul's until later in the nineteenth century, Hornor hired him to implement his system at the Colosseum, in which painters were arranged on distributed, suspended platforms. ${ }^{60}$ Parris would eventually be made responsible for executing and supervising the production of the entire painting — thus instantiating an odd link between the Colosseum's painted surfaces and Thornhill's frescos beneath the site of Hornor's summer-long observations. The interior surface of Thornhill's painting is, in a sense, turned inside out, inscribed instead with the image of the city in which St. Paul's itself was immersed.

As with Hornor's complex negotiation with London's atmosphere during his observations from St. Paul's, the unruly nature of the city's air shaped—and almost scuttled—his plans for a vast panoramic painting. Parris needed to devise a means by which Hornor's hundreds of sketches, however precise, could be translated onto a canvas of more than 24,000 square feet, while preserving the visual and atmospheric unity of the image. "[T]he commencement and finishing of lines, colours and forms," as one account of the panorama's production notes, "must be made to unite and strictly amalgamate," given that the picture "requires unity, harmony, accuracy of linear and aërial perspective." ${ }^{\prime 61}$ The regulation of light and atmosphere continued to pose the greatest problem to Hornor's project. Painters working on individual squared-off sections, for example, would treat the illumination of the ground inconsistently, or depict the smoke emanating from chimneys as moving in opposite directions. ${ }^{62}$ The unruly nature of air's depiction thus threatened to foil the principle of regularity that Hornor and Parris attempted to impose upon London. This smoothed-out view depended upon a principle of amalgamation that could unite London's fractious urban landscape under its newly cleansed atmosphere. ${ }^{63}$ 
Descriptions of Hornor's panorama note, without exception, the unattainable clarity of the image: one's chances of getting a view from St. Paul's itself, after all, "must entirely depend on the clearness of the medium through which we have vision, and that is always in some degree rendered less transparent by the chimneys of this vast town." In the panorama, on the other hand, a visitor can have "certain confidence that he will see what he desires to behold, whatever the state of the weather may be." ${ }^{\prime 64}$ The prominence of the aerial aspect of the Colosseum's apparatus was emphasized by the vast expanse of sky that covered the interior dome and fully half of the painted surface. This "transparent canvass, painted in an imitation of sky" was "strained underneath the lantern-light," such that the illumination of the space from the exterior and the painted atmosphere within might converge.$^{65}$ The sky, as one account described it, was "managed with ... much art and delicacy," while not being "obtrusive." 66 The problem of the “obtrusive" sky links Hornor's painting with broader issues facing naturalist landscape painting in this moment. In his well-known 1821 letter about the painting of skies, John Constable locates the "difficulty [of skies] in painting": despite their "brilliancy and consequence, they ought not to come forward or be hardly thought about in a picture — any more than extreme distances are." ${ }^{97}$ Hornor's painting depended even further on ensuring that air took on an unobtrusive presence, just as atmospheric perspective helped to obscure "extreme distances." While London's atmosphere would normally "come forward" into the space of the observer and obliterate the view, in Hornor's painting the vaporous grounding of the image recedes to an enframing, almost unconscious position.

This painted surface was not the only element securing Hornor's vision of a transparent urban atmosphere; it also required the air enclosed under its broad dome, which what one writer termed the Colosseum's "architectural mechanism." ${ }^{68}$ Beyond filling the internal spacing 
necessary for the picture's illusion, the heated, ventilated air circulated through spectators' bodies. While the mechanisms of the Colosseum's heating systems are unknown, Burton was by this time likely familiar with recent advances in steam heating technologies, which were developed in industrial mills and later applied to greenhouses and other temperature-regulated interiors. ${ }^{69}$ Air thus transited between states in the Colosseum—serving both as the subject of pictorial regulation and the material element that produced the Colosseum's transparent, controlled space of perception.

\section{The Discordant City}

Having entered into the Colosseum's space of artificial comfort, what exactly would a visitor see? One account of the panorama published in the London Magazine describes how Hornor was able to "overcome the difficulties which the smoke of the vast city ordinarily presented" and record the city as if stilled in the moment before the "one dense cloud of London was ... formed." ${ }^{.70}$ In the vision of the city Hornor achieved in his observatory, one could see "[t]he brilliancy of the atmosphere - the almost perfect stillness of the streets ... the few living beings that pass along [the streets] which in the day are crowded like some vast mart." ${ }^{, 11}$ Yet the panorama's view, rather than eliciting civic boosterism, instead evidenced the "desperate energy of commercial adventure" and the "accumulation of wealth" in the city, prompting the writer to enumerate London's miseries: the "dark-looking" complex of Newgate Prison, the "hovels" of Spitalfields, the charitable organizations "feasting" upon the "surplus of the rents of the nineteenth century. ${ }^{, 72}$ Hornor and his associates—-both the patrons of his earlier surveying work, and speculators like Nash — were the ones "feasting" upon the produce of such immiseration and, in the process, remaking London's landscape. ${ }^{73}$ 
This progressive remaking of the urban environment is prominent in an opposing interpretation of the panoramic view given in The Penny Magazine - one that amplified the ideologies of enclosure and improvement that had shaped Hornor's work as a surveyor. ${ }^{74}$ By this account, the stillness and atmospheric transparency of the panorama allowed (as Hornor had intended) the viewer to internally narrate the rapid development of London into a center of trade and imperial expansion. The remainder of the author's account is devoted to a broader précis on "Capital and Labour." Therein, the writer (most likely Charles Knight, the magazine's editor) makes clear what this transparent view looked like from the perspective of the capitalist. ${ }^{75}$ The expansion of London depicted in the panorama is linked to the process of "accumulation" and improvement: in a "civilized country, such as England," the land is "cleared," the "unhealthy marshes are drained," rivers are "narrowed to bounds which limit their inundation," the "country is covered with roads and canals," and common language and law unite its inhabitants in commercial "intercourse." 76 All of these improvements form the "very scaffolding, if we may so express it, of the social structure." The end result is that, in such a prosperous nation, "capital is heaped up on every side by ages of toil and perseverance."77

Knight's narrative of "improvement" tells a tale that leads from the country to the city, and from enclosure to capital accumulation. Indeed, the Colosseum's opening in 1829 coincided with a shift during the 1820 s and 1830s in the energy regimes shaping British industrialization: that from water-powered factories in rural landscapes to fossil-fuel-derived steam power and increasingly urbanized sites of production. ${ }^{78}$ Abetted by the unobtrusive clarity of Hornor's panorama, Knight's narrative envisions an inevitable movement toward such "heaping" of capital. But such shifts were, of course, violently exploitative. As Andreas Malm shows, industrialists did not embrace fossil-fuel-powered machinery until the years around 1830, when 
the land-bound advantages of water power became less attractive to business than an abundant, endlessly replaceable urban labor market. ${ }^{79}$ Such geographies of labor were set into global geographies of "intercourse," in which domestic coal powered the transformation of raw materials derived from enslaved and unfree laborers. ${ }^{80}$

Knight's description of a disciplinary, standardized society that permits the accumulation of capital "all around" suggests how Hornor's regulatory vision formed a condition of possibility for speculative modes of viewing landscape in early nineteenth-century London. To insist upon the real presence of the smoky, choked air of the city might have provided signs of the actual labor necessary for the "heaping" of capital around the spectator of the panorama-whether the worker heating their home or the infernal space of the gas retorts supplying the city's infrastructure. Instead, suspended in the air on their own scaffolding, moving as if effortlessly, the painters of Hornor's panorama united the "component parts" of capital under a condition of unmitigated visibility. Indeed, we might say that scaffolding was the fundamental technology behind Hornor's project of atmospheric regulation, as the site of both his observations and of the panorama's painting. Scaffolding's provisional, suspended nature characterized the forms of "improvement" that were transforming London. But Hornor himself failed in his attempts to participate in this culture of speculation and the "building up of capital on all sides." The fall was precipitous. Debts mounted during the lengthy time of the panorama's gestation, compounded by the financial failure of his backer and pressure from creditors, and Hornor fled London in 1829, leaving the Colosseum to be taken over by a series of trustees. ${ }^{81}$

The conflicts of interpretation that arose in encounters with the Colosseum did not play out only in print. In the years following Hornor's abandonment of the enterprise, the building would continue be a site of contestation over the control of urban space and its perceptual 
atmosphere. Now, however, a different form of airborne pollution was at issue - that of noise rather than of particulate matter. If Hornor's panorama had been conceived of as an "ornament" to the Regent's Park development, the prosperous neighbors residing in Nash's terraces did not agree. Neighbors submitted numerous complaints about noise from the Colosseum. For example, a letter of 1830 despairs of the "screaming of some peafowls" kept in the gardens. The birds "rend forth the loudest and most discordant noises, which are re-echoed by the walls of the houses that surround the place of their confinement." ${ }^{82}$ But it was the noise generated by the panorama's visitors that caused the most concern. By 1835, the owners and tenants of the houses surrounding the Colosseum were so incensed that they made a formal petition to the board overseeing the Crown's lands. In this petition they objected to the Colosseum's transformation “into a place of public resort and evening amusement." Not only did this bring an influx of "disorderly and dissolute persons of the lowest order" into the neighborhood; residents also had to suffer the "inordinate and discordant noise of [musical] performances, within [the Colosseum], and the shouting of voices, calling for Carriages or quarrelling." ${ }^{83}$ These "discordant" phenomena - the radiations of the atmosphere of sound, light, and sociability enjoyed by the visitors within the Colosseum_-"painfully disturbed" the "peace and composure" of all the surrounding residents. More troublingly, it also threatened to "depreciate[e] the value of Houses, in the Neighborhood." 84 The air within and without the Colosseum, despite Hornor's transparent, ordered view, was thus conceived as the conveyor of unregulated sensory stimuli.

To take documents such as noise complaints into account in a discussion of the panorama is also to consider how even the most highly refined mechanisms of nineteenth-century spectacle did not always function as smoothly as their designers - or their interpreters — would have 
wanted ${ }^{85}$ The entropic movement of the city and its noisy air, not to mention the fever pitch of class conflict in the early 1830s, complicated the pictorial and spatial order that Hornor's panorama attempted to exert upon it. Such disturbances originating from the Colosseum, as with the metropolis's smoky air, were a signal product of London's wild density and heterogeneity. The visitors to the Colosseum had ways of using the streets and spaces of the city that worked against the genteel scaffolding of the city's nineteenth-century speculative development. These sonic spectacles unfolding in the panorama sent unwelcome noise echoing across Regent's Park - airborne signals of the city's contested spatial transformation that were beyond the building's capacity to regulate. 


\section{NOTES}

${ }^{1}$ On the centrality of St. Paul's to the imagination of London's urban fabric, see, for example, Dana Arnold, Re-presenting the Metropolis: Architecture, Urban Experience, and Social Life in London 1800-1840 (2000; London: Routledge, 2017), 1-24; and Stephen Daniels, “The Prince of Wales and the Shadow of St. Paul's," in Fields of Vision: Landscape, Imagery, and National Identity in England and the United States (Princeton: Princeton University Press, 1993), 11-42. ${ }^{2}$ John Evelyn, "To the Reader" in Fumifugium: or, the Inconveniencie of the Aer and Smoak of London Dissipated. Together with some Remedies humbly proposed (London, 1661), n.p. For a recent history of preindustrial smoke pollution in London, with an emphasis on Evelyn, see William Cavert, The Smoke of London: Energy and Environment in the Early Modern City (Cambridge, UK: Cambridge University Press, 2016).

${ }^{3}$ For useful overviews, see Peter Brimblecombe, The Big Smoke: A History of Air Pollution in London since Medieval Times (London and New York: Methuen, 1987); and Christine L. Corton, London Fog: The Biography (Cambridge: Belknap Press of Harvard University Press, 2015), esp. 1-36. Corton gives figures for London's population growth on page 14.

${ }^{4}$ These efforts culminated in the 1821 Smoke Nuisance Abatement Act. This legislation, which putatively allowed for legal recourse against "nuisances" caused and damage inflicted by steam engine operators, did not make a significant impact, however. See Carlos Flick, "The Movement for Smoke Abatement in 19th-Century Britain," Technology and Culture 21, no. 1 (January 
1980): 30-31. On the longer history of smoke abatement, the cultural history of pollution, and the role of state-sponsored scientific expertise, see Peter Thorsheim, Inventing Pollution: Coal, Smoke, and Culture in Britain since 1800 (Athens: University of Ohio Press, 2006); and Mark Whitehead, State, Science and the Skies: Governmentalities of the British Atmosphere (Chichester, UK: Wiley-Blackwell, 2009). See, from the perspective of literature, Jesse Oak Taylor, The Sky of Our Manufacture: The London Fog in British Fiction from Dickens to Woolf (Charlottesville: University of Virginia Press, 2016).

${ }^{5}$ Several manufacturers and inventors of smoke-consuming chimneys were interviewed in 1819 and 1820 by the Select Committee on Steam Engines and Furnaces, led by Member of Parliament Michael Angelo Taylor in the House of Commons. See Report from the Select Committee on Steam Engines and Furnaces, \&c. (London, 1819); and Report from the Select Committee on Steam Engines and Furnaces, \&c. (London, 1820). John Wakefield-whose mode of constructing boilers that partially burned the smoke they produced was represented by the image reproduced here — had earlier worked with Matthew Boulton and James Watt in 17901791 at the Piccadilly cotton mill in Manchester. See Stephen Mosley, The Chimney of the World: A History of Smoke Pollution in Victorian and Edwardian Manchester (Abingdon, UK: Routledge, 2008), 123.

${ }^{6}$ Hornor's panorama has played a central role in accounts of "panoramania." The narrative of its construction, reception, and afterlives is well documented in the foundational work of Richard Altick, Ralph Hyde, and others, on whose accounts I rely but from whose conclusions I sometimes depart. See Ralph Hyde, “Thomas Hornor: Pictural Land Surveyor,” Imago Mundi 29 (1977): 23-34; Richard D. Altick, The Shows of London (Cambridge: Belknap Press of Harvard University Press, 1978), 141-62; Ralph Hyde, Panoramania! The Art and Entertainment of the 
'All-Embracing' View (London: Trefoil Publications, in association with Barbican Art Gallery, 1988), 79-96; Ralph Hyde, The Regent's Park Colosseum or, "Without Hyperbole, the Wonder of the World," Being an Account of a Forgotten Pleasure Dome and Its Creators (London: Ackermann, 1982); Arnold, Re-presenting the Metropolis, 2-5; Stephen Oettermann, The Panorama: History of a Mass Medium (Brooklyn: Zone Books, 1997), 132-40; John Brewer, "Sensibility and the Urban Panorama," Huntington Library Quarterly 70, No. 2 (June 2007): 229-49; Dana Arnold, "Panoptic Visions of London: Possessing the Metropolis," Art History 32, No. 2 (April 2009): 340-45; Peter Otto, “Artificial Environments, Virtual Realities, and the Cultivation of Propensity in the London Colosseum," in Virtual Victorians: Networks, Connections, Technologies, ed. Veronica Alfano and Andrew Stauffer (New York: Palgrave Macmillan, 2015), 167-87; and Peter Otto, Multiplying Worlds: Romanticism, Modernity, and the Emergence of Virtual Reality (Oxford, UK: Oxford University Press, 2011), 266-96. As with Hyde's early article, Otto's work in particular trains attention upon Hornor's career taken as a whole, as this article does; his discussion of the Colosseum as a social space of immersion intersects at points with mine but is focused more on questions of the "virtual" experience it staged for visitors (see especially “Artificial Environments, Virtual Realities”). For a key account that reinterprets the panorama's broader impact upon nineteenth-century visuality, see Jonathan Crary, "Géricault, the Panorama, and Sites of Reality in the Early Nineteenth Century," Grey Room, no. 9 (Fall 2002): 5-25. For a recent, incisive overview of the panorama and its historiography, see Katie Trumpener and Tim Barringer, "Introduction," in On the Viewing Platform: The Panorama between Canvas and Screen, ed. Katie Trumpener and Tim Barringer (New Haven: Yale University Press, 2020), 1-39, esp. 5-20. My thanks to Tim Barringer for sharing this with me in advance of its publication. 
7 "Circumambient air" was a frequently used term for what we might call atmosphere; see "Circumambient," in Abraham Rees et. al., The Cyclopadia; or Universal Dictionary of Arts, Sciences, and Literature, Vol. 8 (London: Longman, Hurst, Rees, Orme, \& Brown, 1819). My consideration of the panorama is situated within a broader problematic identified by Eric C.H. de Bruyn - that is, art history's "limited set of concepts to define the multiple levels and circuits of exchange between art and its 'surround,' whether this is considered in an architectural, economic, social, technological, informational ... sense" and the concomitant need to investigate the "dialectics" between "ecological systems and ... systems of observation." See de Bruyn, “A Proposal: Must We Ecologize?” Grey Room, no. 77 (Fall 2019): 60, 63. For a rich account of "the idea of the medium as a sensible, atmospheric environment" in the early nineteenth century, see Antonio Somaini, "The Atmospheric Screen: Turner, Hazlitt, Ruskin," Screen Genealogies: From Optical Device to Environmental Medium, ed. Craig Buckley, Rüdiger Campe, and Francesco Casetti (Amsterdam: Amsterdam University Press, 2019), 15985.

${ }^{8}$ As Michel Foucault would posit (in a footnote) in his discussion of Jeremy Bentham and the "sovereign gaze" of the Panopticon, visitors to Barker's panorama "occupied exactly the place of the sovereign gaze." See Michel Foucault, Discipline and Punish: The Birth of the Prison, trans. Alan Sheridan (1975; New York: Vintage Books, 1995), 317n4.

${ }^{9}$ In this sense, we can locate his project within the longer trajectory of Western picturing's contention with the disruptive materiality of cloud and air that Hubert Damisch charts in $A$ Theory of /Cloud/: Toward a History of Painting, trans. Janet Lloyd (1972; Stanford, CA: Stanford University Press, 2002). 
${ }^{10}$ Michael Osman, Modernism's Visible Hand: Architecture and Regulation in America

(Minneapolis: University of Minnesota Press, 2018), viii. Osman's account, while focused on the United States, begins with the debates around ventilation and the management of air during the redesign of the Houses of Parliament in the 1840s.

${ }^{11}$ My arguments here build on Arnold's accounts of Hornor's panorama within the context of London's speculative development and commodified "re-presentation": see Arnold, "Panoptic Visions," 332-350; and Arnold, Re-presenting the Metropolis.

${ }^{12}$ Hyde, “Thomas Hornor," 23-34; Hyde, Regent's Park Colosseum, 11. On Hornor's surveys, see also Otto, Multiplying Worlds, 268-72.

${ }^{13}$ See Sarah Bendall, "Estate Plan" and "Property Mapping in Great Britain," The History of Cartography, Volume 4: Cartography in the European Enlightenment, ed. Matthew H. Edney and Mary Sponberg Pedley (Chicago: University of Chicago Press, 2020), 1133-38, 1171-75. See also Ian D. Whyte, Landscape and History since 1500 (London: Reaktion Books, 2002), 94; and Ron Broglio, Technologies of the Picturesque: British Art, Poetry, and Instruments, 17501830 (Lewisburg: Bucknell University Press, 2008), 57. This rise in private surveys developed in tandem with the British state's increasing emphasis on the survey as a mode of military and colonial control (e.g., the military surveys of Scotland after the Jacobite rebellion). See Caren Kaplan, Aerial Aftermaths: Wartime from Above (Durham, NC: Duke University Press, 2018), $34-67$.

${ }^{14}$ For the foundational histories of British landscape painting and the politics of enclosure, see John Barrell, The Dark Side of the Landscape: The Rural Poor in English Painting 1730-1840 (Cambridge, UK: Cambridge University Press, 1980); David Solkin, Richard Wilson: The Landscape of Reaction (London: Tate Gallery, 1982); and Ann Bermingham, Landscape and 
Ideology: The English Rustic Tradition, 1740-1860 (Berkeley and Los Angeles: University of California Press, 1986).

${ }^{15}$ On the way in which the "perpetual retrospect to an 'organic' or 'natural' society" was a key structuring "myth" in the age of enclosure, see Raymond Williams, The Country and the City (Oxford, UK: Oxford University Press, 1973), 96-107.

16 Thomas Hornor, Description of an Improved Method of Delineating Estates, with a Sketch of the Progress of Landscape Gardening in England, and Opinions on the Picturesque Effects Attempted in Rural Ornament (London: J. Harding, 1813), 5.

${ }^{17}$ On this movement between aerial and ground-based views in Hornor's surveys, see Otto, Multiplying Worlds, 270.

${ }^{18}$ Hornor, Improved Method, 13. On the survey's originary aerial positionality_- “an embodied form of perception, as if flying far above the earth"- - see Kaplan, 36; emphasis in the original. ${ }^{19}$ Hornor, Improved Method, 14.

${ }^{20}$ Leonardo da Vinci, A Treatise on Painting, trans. Jean François Rigaud (London: J. Taylor, 1802), 158-79. On Rigaud's translation and the afterlives of da Vinci's text in the nineteenth century, see Janis Bell, “Rigaud’s Popular Translation of Leonardo’s Treatise on Painting (1802)," in Leonardo in Britain: Collections and Historical Reception, ed. Juliana Barone and Susanna Avery-Quash (Florence: Leo S. Olschki, 2019), 243-65.

${ }^{21}$ T.H. Fielding, Synopsis of Practical Perspective Lineal and Aerial (London, 1829), 116. Fielding's comment is one of several early nineteenth-century descriptions of the system of aerial perspective as a means to regulate pictorial distance. The sense that British landscape painting had perhaps gone too far in emphasizing the aerial medium of vision was suggested in 
William Hazlitt's notorious aside casting J.M.W. Turner's paintings as “too much abstractions of aerial perspective.” Hazlitt, “On Imitation,” in The Round Table, vol. 2 (Edinburgh, 1817), 19.

22 This vertical materialization of air should be connected to what Kaplan calls "aerostatic spacing" in her genealogy of aerial images - tied specifically to the aerial views in Thomas Baldwin's Airopaidia (1786). See Kaplan, 76-95.

${ }^{23}$ Hornor, Improved Method, 11.

${ }^{24}$ Hornor, Improved Method, 10.

${ }^{25}$ See Otto, Multiplying Worlds, 282-83. Hyde also notes Edwards Vaughan's position as a “wealthy London solicitor": (Hyde, “Thomas Hornor,” 26). For an overview of Edwards Vaughan, see Terry Jenkins, “Edwards Vaughan (Formerly Edwards), John (1772-1833)," in The History of Parliament: The House of Commons 1820-1832, ed. D.R. Fisher (Cambridge, UK: University of Cambridge Press, 2009), https://www.historyofparliamentonline.org/volume/1820-1832/member/edwards-vaughan-john1772-1833. For more on Hornor's work in Wales, including his connections to Edwards Vaughan and Nash, see Elis Jenkins, “Thomas Hornor,” Glamorgan History, vol. 7 (Cowbridge, UK: D. Brown and Sons, 1971), 37-50.

${ }^{26}$ See John Summerson, The Life and Work of John Nash: Architect (Cambridge: MIT Press, 1980), 26-28, 69-73, 141-42, 170-74.

27 Jenkins, "Edwards Vaughan."

${ }^{28}$ On this watercolor, see Bethany MvIntyre, cat. no. 53, in Tim Barringer and Oliver Fairclough, Pastures Green and Dark Satanic Mills: The British Passion for Landscape (New York: American Federation for the Arts; London: D Giles, 2014), 150. 
${ }^{29}$ For references, see Summerson, 27; entry on "Cadoxton," in Samuel Lewis, A Topographical Dictionary of Wales, 2nd ed., Vol. II (London: S. Lewis, 1840), upg. The archives of the Rheola estate include numerous documents relating to mineral and coal extraction on the estate and surrounding region, beginning around 1800. See Annual Report of the National Library of Wales (Aberystwyth: National Library of Wales, 1965), 24-25.

${ }^{30}$ This is not to say that coal from South Wales was supplying London's domestic fires and manufactures in this moment. The products of the South Wales coal fields remained in relatively regional circulation until the 1840s, when the mining of steam coal and the advent of railroad networks led to its much wider application; moreover, the coal mined in this area before the 1840s was mostly not suitable for domestic use in London. See A. H. John, The Industrial Development of South Wales, 1750-1850 (1950; Cardiff: Merton Priory Press, 1995), 113-22. My thanks to Aleksandr Bierig for his generous advice and suggestions on this point.

${ }^{31}$ We might see Hornor's repeated insistence on picturing and describing his observatory as one of the kinds of "reality effects" that, as Crary writes, abounded in the nineteenth century's cultures of spectacle, such as the engraving of the "Plan of the Raft of the Medusa" that specified the position of the eyewitness narrative of this marine disaster, which would subsequently be replicated in text, painting, and panorama. See Crary, 5-25.

${ }^{32}$ On an earlier version of Hornor's image of his observational apparatus, published in The Mirror on 17 May 1821, and Hornor's means of presenting himself as a kind of "explorer," see Otto, Multiplying Worlds, 284.

${ }^{33}$ Thomas Hornor, Prospectus of a View of London and the Surrounding Country, Taken with Mathematical Accuracy from an Observatory Purposely Erected over the Cross of St Paul's Cathedral (London, 1823), 3. As Hyde notes, the Prospectus was published in two different 
versions and multiple printings in 1822 and 1823. See Hyde, "Thomas Hornor," 29. This returning gaze was not merely imaginary; Hornor complemented his observations from the dome with travel around the city to "collate these sketches with many of the individual objects." Hornor, Prospectus, 23. On this see Bernard Comment, The Painted Panorama, trans. AnneMarie Glasheen (London: Reaktion, 1999), 113-14. This should be connected with the groundlevel measurements of surveying that are translated into the survey's aerial view. See Kaplan, 36. On the ways that Hornor's panorama brings together the possessive, static "view from above" and the dynamic experience of the pedestrian, see Arnold, "Panoptic Visions," 342-45.

${ }^{34}$ On the experience of the pedestrian in the "new bourgeois metropolis" of London, see Arnold, Re-presenting the Metropolis, 25-42; and Lynda Nead, Victorian Babylon: People, Streets, and Images in Nineteenth-Century London (New Haven: Yale University Press, 2000).

35 Thomas Hornor, "Notice to the Possessors of Property in and around London," ms., ca. 18231825, in Yale Center for British Art, Rare Books and Manuscripts. This notice is found in connection to a corrected proof of a second edition of Hornor's Prospectus.

36 John Barrell, "The Public Prospect and the Private View: The Politics of Taste in EighteenthCentury Britain," in Reading Landscape: Country, City, Capital, ed. Simon Pugh (Manchester: Manchester University Press, 1990), 19-40.

${ }^{37}$ On Hornor's project in the context of the contested boundary between entertainment and scientific inquiry, see Jennifer Tucker, "Voyages of Discovery on Oceans of Air: Scientific Observation and the Image of Science in an Age of 'Baloonacy,"' Osiris 11 (1996): 157. ${ }^{38}$ Hornor, Prospectus, 17-18.

${ }^{39}$ Hornor, Prospectus, 15-17. For his sketching, Hornor used a focusing device likely related to Cornelius Varley's graphic telescope. On the graphic telescope, see Charlotte Klonk, Science 
and the Perception of Nature: British Landscape Art in the Late Eighteenth and Early Nineteenth Centuries (New Haven and London: Yale University Press, 1996), 130-35.

40 “"The Stranger: No. II,” Morning Post, 27 March 1823, 3. For a survey of newspaper and journal accounts of Hornor's exploits and the afterlife of the Colosseum, see Altick, 141-62; and Hyde, The Regent's Park Colosseum.

${ }^{41}$ See Greg Smith et al., Thomas Girtin: The Art of Watercolour (London: Tate Publishing, 2002), 188-205; and Greg Smith, “The ‘Connoisseur's Panorama’: Thomas Girtin’s Eidometropolis (1801-1803) and a New Visual Language for the Modern City," British Art Studies 10 (2018), https://www.britishartstudies.ac.uk/issues/issue-index/issue-10/girtinpanorama.

42 "Monthly Retrospect of the Fine Arts," Monthly Magazine 14 (October 1802): 254-55, quoted in Oettermann, 120.

${ }^{43}$ Smith, "The 'Connoisseur's Panorama."” For other discussions of smoke as a defining characteristic of London and urban modernity, see William Cavert, "Urban Air Pollution and The Country and the City," Global Environment 9, no. 1 (2016): 149-65; and Taylor, 2.

${ }^{44}$ John Bonehill and Stephen Daniels, "Projecting London: Turner and Greenwich," Oxford Art Journal 35, no. 2 (2012): 171-94.

${ }^{45}$ On the maps that Turner represents in the context of the history of London's development, see Bonehill and Daniels, "Projecting London," 180-84.

${ }^{46}$ See Arnold, Re-presenting the Metropolis, 4.

47 “Specification of the Patent granted to Mr. Robert Barker, of the City of Edinburgh . . . for his Invention of an entire new Contrivance or Apparatus, called by him La Nature à Coup dGEil . . dated June 19, 1787," Repertory of Arts and Manufactures, vol. 4 (London, 1796): 165-67. 
${ }^{48}$ The panoramic structure thus relates to broader nineteenth-century investigations into controlled milieus of sensory experience and experiment—for example, the greenhouse and the aquarium—which developed as key spaces of calibrated investigation and sensory experience. See Christina Wessely, "Watery Milieus: Marine Biology, Aquariums, and the Limits of Ecological Knowledge circa 1900," Grey Room 75 (Spring 2019): 36-59. Otto suggests such connections between the Panorama and other enclosed, artificial environments of sociality, like the Crystal Palace. Otto, "Artificial Environments, Virtual Realities," 182-83. See also Richard Maxwell with Katie Trumpener, "Panorama, Glasshouse, Museum: Alexander von Humboldt, Franz Boas, Gustaf Kolthoff," in On the Viewing Platform, 154-69.

${ }^{49}$ On the Eidophusikon, see Altick, 117-27; Iain McCalman, "Magic, Spectacle, and the Art of de Loutherbourg's Eidophusikon," in Sensation and Sensibility: Viewing Gainsborough's “Cottage Door," ed. Ann Bermingham (New Haven: Yale Center for British Art, 2005), 18197; and Ann Bermingham, “Technologies of Illusion: De Loutherbourg's Eidophusikon in Eighteenth-Century London," Art History 39, no. 2 (April 2016): 376-99.

${ }^{50}$ On the Diorama in London, see Altick, $163-72$.

${ }^{51}$ Brewer, 236. See, also, Markman Ellis, “'Spectacles within Doors': Panoramas of London in the 1790s," Romanticism 14, no. 2 (July 2008): 133-48

${ }^{52}$ Oettermann briefly considers "Hornor's view" as "that of the real estate agent" or a "mailorder catalogue," though he does not connect this to the Colosseum's position in London's landscape. See Oettermann, 137.

${ }^{53}$ See Arnold, Re-presenting the Metropolis, 48-51, 108-09; and Dana Arnold, "A Family Affair: Decimus Burton's Designs for the Regent's Park Villas," in The Georgian Villa, ed. Dana Arnold (Stroud, UK: Alan Sutton, 1998), 105-17. James Burton was familiar with Hornor's 
Improved Method of Delineating Estates with Plates, and Peter Bohan suggests that the elder Burton probably introduced Burton to Hornor. See Peter Bohan, "James and Decimus Burton: Architectural Trends in England Exemplified by Their Work” (Ph.D. diss., Yale University, 1961), 48n29.

54 John Nash, “Report on Mr Hornor's application for Ground in Marylebone Park on which to erect a building to exhibit a Panorama of London, Jan 11, 1824," in National Archives, CRES $2 / 777 / 15$. The negotiations for the design of the building and rent of the land were subject to the calculating logic of street frontage upon which Nash's speculation was founded. See John Nash, "Returning [draft] Agreement with Mr Hornor for a building lease of ground east side of Marylebone Park," 19 January, 1824 in National Archives, 2/777; and John Nash, "Report on Mr Hornor's appl'n for additional ground," May 17, 1824, National Archives, CRES 2/777.

${ }^{55}$ See Hornor, Sketches in the Grounds of Marshalls, the Seat of Rowland Stephenson, Esq., 1824, in Yale Center for British Art, Rare Books and Manuscripts.

${ }^{56}$ Hyde, Regent's Park Colosseum, 21, 28-37.

57 “The Colosseum," Sun, 10 October 1829, 1.

58 “The London Colosseum,” The Kaleidoscope, 20 January 1829, 239.

${ }^{59}$ For a detailed description of the process of completing the painting, one on which I have relied for this article, see Altick, 142-46. See also Hyde, The Regent's Park Colosseum, 23-28.

${ }^{60}$ On Thornhill's paintings, see Richard Johns, “'An Air of Grandeur and Modesty’: James Thornhill's Painting in the Dome of St. Paul's Cathedral," Eighteenth-Century Studies 42, no. 4 (Summer 2009): 501-27. On the later employment of Parris's system, from which this illustration is drawn, see "Restoration of the Paintings in the Dome of St. Paul's," Illustrated London News, December 24, 1853, 560-62. 
${ }^{61} \mathrm{~J}[\mathrm{ohn}] \mathrm{B}[\mathrm{ritton}]$, A Brief Account of the Colosseum in the Regent's Park, London ... (London: Printed for the proprietors, 1829), 7.

62 “The Colosseum," Literary Gazette, 17 January 1829, 43; Hyde, Regent's Park Colosseum, 27.

${ }^{63}$ On the broader history of visual technologies as means to "delimit" as well as to "stimulate" sensory experience in nineteenth-century London, see Christopher Otter, "Cleansing and Clarifying: Technology and Perception in Nineteenth-Century London," Journal of British Studies 43, no. 1 (January 2004): 40-64.

64 "The Colosseum," London Courier and Evening Gazette, 4 January 1830, 1.

65 “The Colosseum, Regent's Park," New Monthly Magazine and Literary Journal, October $1829,434$.

66 “"The Colosseum," Literary Gazette, 42.

${ }^{67}$ John Constable to John Fisher, 23 October 1821, in John Constable's Correspondence, vol. 12, ed. R.B. Beckett (Ipswich: Suffolk Records Society, 1968), 77.

68 "The Colosseum, Regent's Park," 433. On the panorama and the function of distance in the mechanics of illusion, see Comment, 110-14; and Crary, 19-20.

${ }^{69}$ Burton had incorporated technologically sophisticated conservatories into his designs for villas in Regent's Park in the early 1820s and would later be partially responsible for some of the most advanced glass structures (and horticultural heating systems) in Britain, including the Winter Garden in Regent's Park and the Palm House at Kew, both completed in the 1840s. See, among others, Edward J. Diestelkamp, "Fairyland in London: The Conservatories of Decimus Burton," Country Life, 19 May 1983, 1,342-44; and Dana Arnold, "The Architect and the Metropolis: The Work of James and Decimus Burton in London and Dublin, c. 1800-1840” (Ph.D. diss., 
University of London, 1997), 133-34. Advertisements for the Colosseum repeatedly noted the functioning of the building's ventilation and heating structures, reminding visitors in December 1832 that the "whole of the interior is now lighted up and thoroughly warmed for the Season." “The Colosseum, Regent's Park," Morning Advertiser, 12 December 1832, 2. In 1835, the building had a new "pipes and warm air apparatus" installed—perhaps signaling a steam-heated system; see Hyde, The Regent's Park Colosseum, 47.

70 “The Colosseum," London Magazine, February 1829, 104-5; emphasis in original. 71 “The Colosseum," London Magazine, 104.

72 “The Colosseum,” London Magazine, 106-8.

${ }^{73}$ The commissioner of Hornor's view of Rheola—Edwards Vaughan — would be targeted for such greed. Vaughan had owned the Southwark Water Works, central to the city's water supply, since 1822. By 1832, George Cruickshank had published a caricature of him and the Waterworks, decrying his "liquid corruptions" and the "excrementitious" water the company supplied. See George Cruikshank, Source of the Southwark Waterworks, 1832, engraving and letterpress.

${ }^{74}$ [Charles Knight], "The Colosseum," Monthly Supplement of the Penny Magazine of the Society for the Diffusion of Useful Knowledge, 28 February-31 March 1833, 121-22. This article repeats verbatim the description of the "stilled" atmosphere given in the account from the London Magazine. On this passage, and the critique of London it offers, as reflecting the “differential between the actual and virtual," see Otto, "Artificial Environments, Virtual Realities,"174-75. 
75 The passages in the article are quoted from the Society for the Diffusion of Useful Knowledge's treatise on “Capital and Labour," published as Charles Knight, The Rights of Industry, vol. 1 (London: Charles Knight, 1831).

${ }^{76}$ [Charles Knight], “The Colosseum,” Penny Magazine, 122. Knight summarizes the centurieslong process of "improvement" and its structuring ideology, one that had transformed the British landscape. See also Vittoria di Palma, Wasteland: A History (New Haven: Yale University Press, 2014). On the idealism and "hyper-realism" of Hornor's panorama as a simultaneous "embrace" of modernity and as a "turn[ing] away" or "refuge" from it, see Brewer, 237-39. On the visual culture that attended the rapid "improvement" of the metropolis in the decades after 1820 , see Alex Potts, "Picturing the Modern Metropolis: Images of London in the Nineteenth Century," History Workshop Journal 26, no. 1 (1988): 34-43.

77 [Knight], "The Colosseum,” 123.

${ }^{78}$ See Andreas Malm, Fossil Capital: The Rise of Steam Power and the Roots of Global Warming (New York: Verso, 2016).

${ }^{79}$ Malm, 121-64. It should be noted, here, that the first panorama of London-exhibited by Robert Barker in the early 1790s_-depicted the city from the rooftop of Albion Mills. This steam-powered flour mill had burned to the ground in 1791, possibly due to arson, and was a locus of worker unrest over its steam-powered displacement of millers - a fact that, as Tim Barringer argues, might have conditioned the divided reception of Barker's panorama between a middling-class "public" and the "people." See Tim Barringer, "The World for a Shilling: The Early Panorama as Global Landscape, 1787-1830," in On the Viewing Platform, 92-98.

${ }^{80}$ See, for example, the discussion of "war capitalism" in Sven Beckert, Empire of Cotton: A Global History (New York: Penguin Random House, 2014); and the geographies of unfree labor 
traced in Lisa Lowe, The Intimacies of Four Continents (Durham, NC: Duke University Press, 2015).

${ }^{81}$ See Altick, 146. For a description of Hornor's entire project as a "speculation"-one "whose “wisdom or . . folly" was uncertain — see "The Colosseum, Regent's Park," New Monthly Magazine, 433. On the failure of George Stephenson's bank and links to the Colosseum, see “Another London Banker Failed," The Examiner, 28 December 1828, 842.

${ }^{82}$ A.G. Stapleton to Commissioners of Woods, Forests and Land Revenues, 28 June 1830, in National Archives, CRES 35/2289/8. This letter is held in a file containing "Complaints of Performances and Nuisances" at the Colosseum from 1827 to 1841.

83 "The humble Petition of the Proprietors and Inhabitants of Houses in the immediate vicinity of the Colosseum in the Regent's Park," to Commissioners of Her Majesty’s Woods and Forests and Land Revenue," 20 July 1835, in National Archives, CRES 35/2289/18.

84 "Petition of the Proprietors and Inhabitants ..."

${ }^{85}$ For a description of the larger world of sociability staged at the Colosseum, see Otto, “Artificial Environments, Virtual Realities," 176-84. On the panorama as a space not necessarily of discipline or imprisonment but as a novel space of free movement enjoyed by a "new, prosperous, and ideologically febrile urban middle class," see Barringer, "The World for a Shilling," 83-106. 